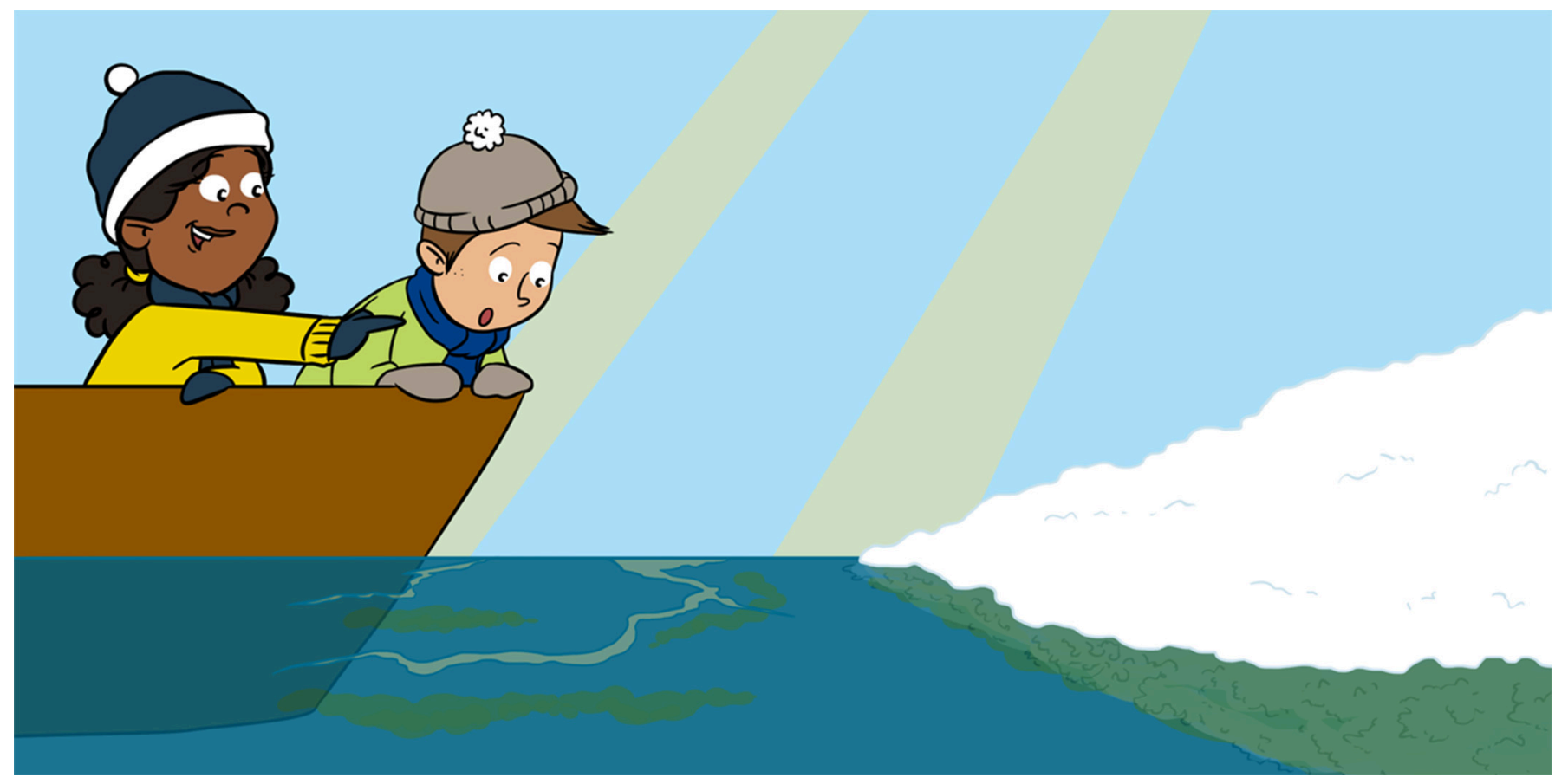

\title{
THE FUTURE OF THE ARCTIC: WHAT DOES IT MEAN FOR SEA ICE AND SMALL CREATURES?
}

Hanna M. Kauko ", Mar Fernández-Méndez ${ }^{\dagger}$, Amelie Meyer ${ }^{\dagger}$, Anja Rösel ${ }^{\dagger}$, Polona Itkin ${ }^{\dagger}$, Robert M. Graham ${ }^{\dagger}$ and Alexey K. Pavlov ${ }^{\dagger}$

Research Department, Norwegian Polar Institute, Tromsø, Norway

\section{YOUNG REVIEWERS}

ST.

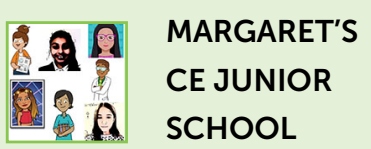

AGES: 9-10
The warming of our planet is changing the Arctic dramatically. The area covered by sea-ice is shrinking and the ice that is left is younger and thinner. We took part in an expedition to the Arctic, to study how these changes affect organisms living in and under the ice. Following this expedition, we found that storms can more easily break the thinner ice. Storms form cracks in the sea ice, allowing sunlight to pass into the water below, which makes algal growth possible. Algae are microscopic "plants" that grow in water or sea ice. Storms also brought thick heavy snow, which pushed the ice surface below the water. This flooded the snow and created slush. We discovered that this slush is another good habitat for algae. If Arctic sea ice continues to thin, and storms become more common, we expect that these algal habitats will become more important in the future. 


\section{ARCTIC}

The Arctic is a polar region located at the northernmost part of the Earth, often defined as the region north of the Arctic Circle $166^{\circ}$ $33^{\prime}$ N). Around $60 \%$ of the Arctic is sea, much of which is covered by year-round sea ice.

\section{SEA ICE}

Sea ice is frozen ocean water. It forms, grows, and melts in the ocean. In contrast, icebergs, glaciers, and ice shelves form on land and are made of fresh water from compacted snow.

\section{OCEAN CURRENTS}

Oceanic currents describe the movement of water from one location to another, similar to wind in the atmosphere. Ocean currents are driven by wind, water density differences, and tides. Ocean currents affect the Earth's climate by driving warm water from the Equator and cold water from the poles around the Earth.

\section{ALGAE}

Organisms that grow in the water and can fix carbon from the atmosphere like plants do on land. In the high Arctic, the algae present are tiny, single-celled organisms.

\section{HABITAT}

A place or area with certain environmental conditions, in which certain type of organisms live.

\section{INTRODUCTION}

Arctic sea ice is the layer of frozen water covering the northernmost ocean on our planet. Sea ice moves constantly in response to ocean currents and winds, and is also sensitive to changes in temperature. It used to be several meters thick and would only partly melt in the summer. With the current increase in temperatures due to climate change, more and more ice melts over the summer. This means that now a larger part of the ice cover is young and thin, because it only had one winter to grow [1]. These changes have consequences for the climate system and for organisms living in the Arctic Ocean (reviewed in [1]). For example, changes in the ice thickness affect the amount of sunlight and heat that reaches the ocean. More heat accumulated in surface waters leads to less ice growth and further ice melt. More sunlight below the ice enables more algal growth in the ocean. Since algae are responsible for food production the same way as plants are on land, it is important to know how many and which type of algae will grow in the Arctic Ocean. This will help us to predict how other organisms, such as fish and sea birds will respond. In 2015, we took part in a research expedition in the Arctic to collect data that will help us address this challenge.

During the research expedition, a Norwegian research ship named Lance was anchored to sea ice exiting the Arctic Ocean (Figures1, 2A; [2]). The ship drifted with the sea ice for half-a-year, without using motor power. From January to June 2015, we used the ship as a base to carry out measurements of the atmosphere, ice, and ocean, such as temperature, snow depth, ice thickness, and the amount and type of algae present (Figure 2). Our measurements from the expedition taught us about new features emerging in the Arctic Ocean as a consequence of ongoing climate change. To learn more about the project go to our webpage www.npolar.no/nice2015 or look for the hashtag \#nice2015arctic on social media. Here we will explain our findings on how changes in sea ice affect the "home" of algae, the sea ice, and underlying ocean habitats.

\section{WHAT MAKES THE ALGAE GROW WHERE THEY GROW?}

We, the sea ice biologists, were especially interested to study the algae. Almost all food in the ocean is produced by algae, which are capable of producing organic sugars using sunlight, just like land plants do. This process is called photosynthesis. In the water column and inside the sea ice, the algae are microscopically small and are called phytoplankton and ice algae, respectively.

In spring, we were surprised to find high amounts of phytoplankton growing in the water under the sea ice [3]. Typically, very little sunlight reaches the water below the sea ice, because it is reflected away by the white ice and snow. Most of the phytoplankton present were of 
Figure 1

A map of the study area, with a drift track of the research ship Lance, sea ice movement patterns, and warm ocean currents indicated with arrows (see legend). The shaded area marks the usual extent of the sea ice cover. Image background is from Blue Marble Next Generation (NASA).

\section{PHOTOSYNTHESIS}

The process in which algae and plants convert, with the help of sunlight, inorganic carbon from the atmosphere or the water into organic compounds, such as sugars, that they use for growth. Other

organisms rely on these sugars and other compounds for their food. In addition, oxygen is released in the process.

\section{DIATOM}

Type of single-celled algae that has a wall made out of a mineral called silicate, which is like glass. They are very abundant in the sea and important in the Arctic food webs. There are many different species of diatoms and they can be identified under the microscope.

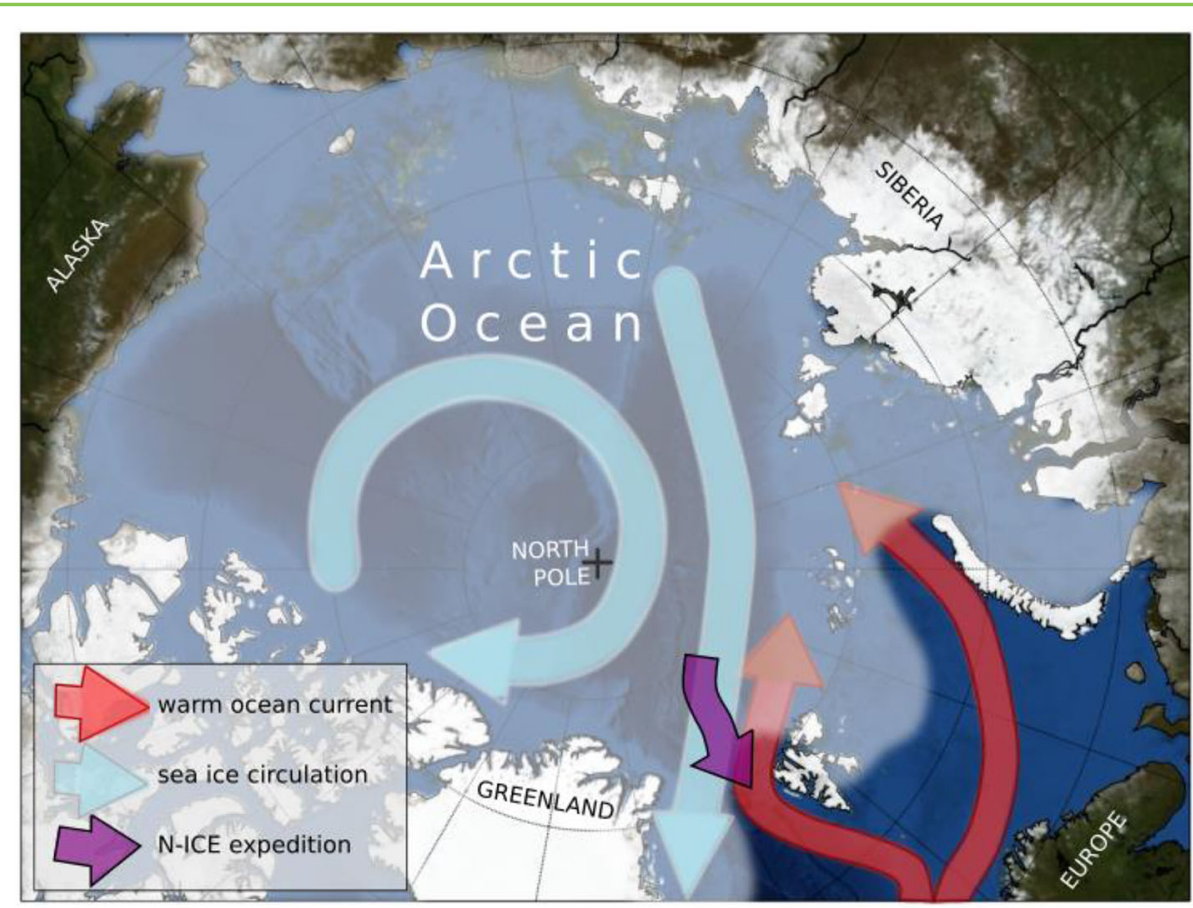

Figure 1

the species Phaeocystis pouchetii (Figure 2D). This algae species is unicellular but the cells can connect together to form colonies, which are up to $0.2 \mathrm{~mm}$ in diameter and which are possible to see with your bare eye.

Later in spring, toward the end of our expedition, we found high amounts of algae on top of the ice, in a layer between the thick snow and the relatively thin ice cover (Figure 2E; [4]). Typically, the main habitat for ice algae is the bottom of the ice which interacts with sea water. When we analyzed these algal communities under a microscope, we found that they consisted of species that are typically found in the water column, such as chain-forming diatoms (Figure 2F). These species are not typical in the sea ice.

To find out how these algae ended up between the snow and ice and what made algal growth possible in these habitats, that is, the different types of "homes," we turned to our oceanography and sea ice physics colleagues to hear what had happened with the ice cover in the previous months (Figure 3).

\section{STORMS BREAK UP ICE FLOES INTO SMALLER PIECES}

Some of the most exciting processes we observed during our research expedition happened during several powerful winter storms. These storms came from the south and brought strong winds, rapid changes in air temperature, and heavy snowfall [5]. 
Figure 2

(A) Research ship Lance frozen in sea ice during the expedition. Some of our research equipment, such as tents and sledges, are visible around the ship. Photo: Seb Sikora. (B) During winter, the sun does not rise in the Arctic. The night continues for $24 \mathrm{~h}$ a day, and work must be completed in darkness. For example, it is hard to see polar bears! Photo: Jago Wallenschus. (C) Sea water sampling through a hole in the sea ice. Photo: Marcel Nicolaus. (D) Photo taken through a microscope of a colony of algae (Phaeocystis pouchetii) observed forming a bloom in the water under the ice. Photo: Jozef Wiktor. (E) Green and brown slush on the ice under the snow: this is algae! Photo: Hanna Kauko. (F) Microscopy picture of a diatom chain: This is the type of algae that we found in the slush. Photo: N-ICE2015 biology team.
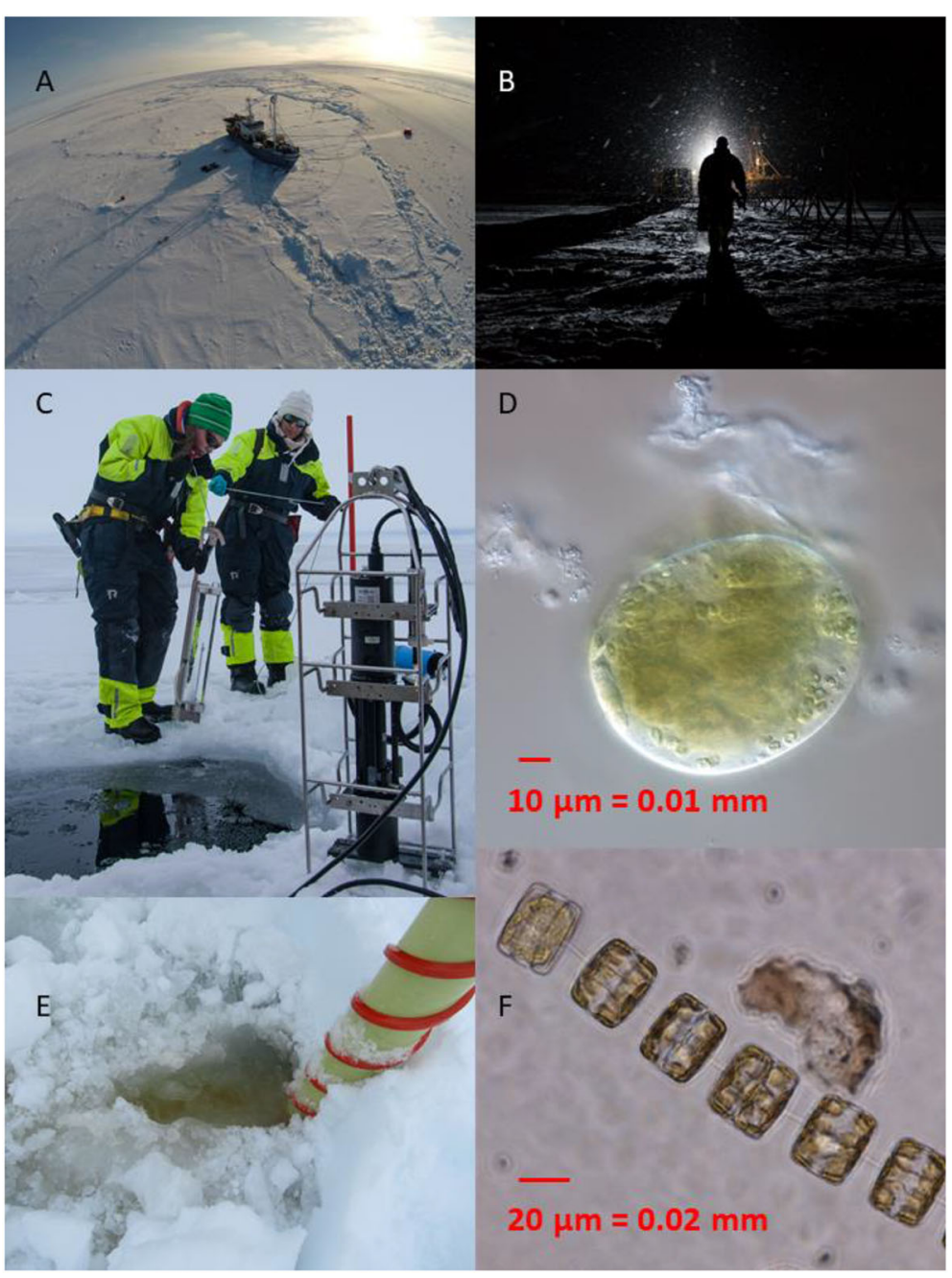

Figure 2

The strong winds during the storms pushed the ice around and broke it into pieces, making it more fragile and deforming it, more like a boulder field [5]. This opened up areas of open water, known as leads. Eventually these leads were covered by thin ice, but they still let high amounts of sunlight pass through, compared with thicker ice covered in snow [6].

Connecting all our findings, we discovered that the leads enabled the algae to grow below the sea ice, by allowing the necessary sunlight to pass through for algal photosynthesis [3]. The algae we found, Phaeocystis pouchetii, can cope with changes between low light under the thick ice and high light intensity under the leads better than some other algae, which may explain its success under this type of ice [3]. 


\section{Figure 3}

During the

expedition, we made

many interesting

biological findings.

Observations of the

physical processes in

the atmosphere, snow,

ice, and ocean during

the winter helped to

explain why the algae

were growing in certain

habitats. Photos that

are used for the

cartoon (in the order

from 1 to 8): Paul Dodd,

Polona Itkin, Paul

Dodd, Seb Sikora, Mar

Fernández-Méndez,

Marcel Nicolaus, Mar

Fernández-Méndez,

Amelie Meyer.

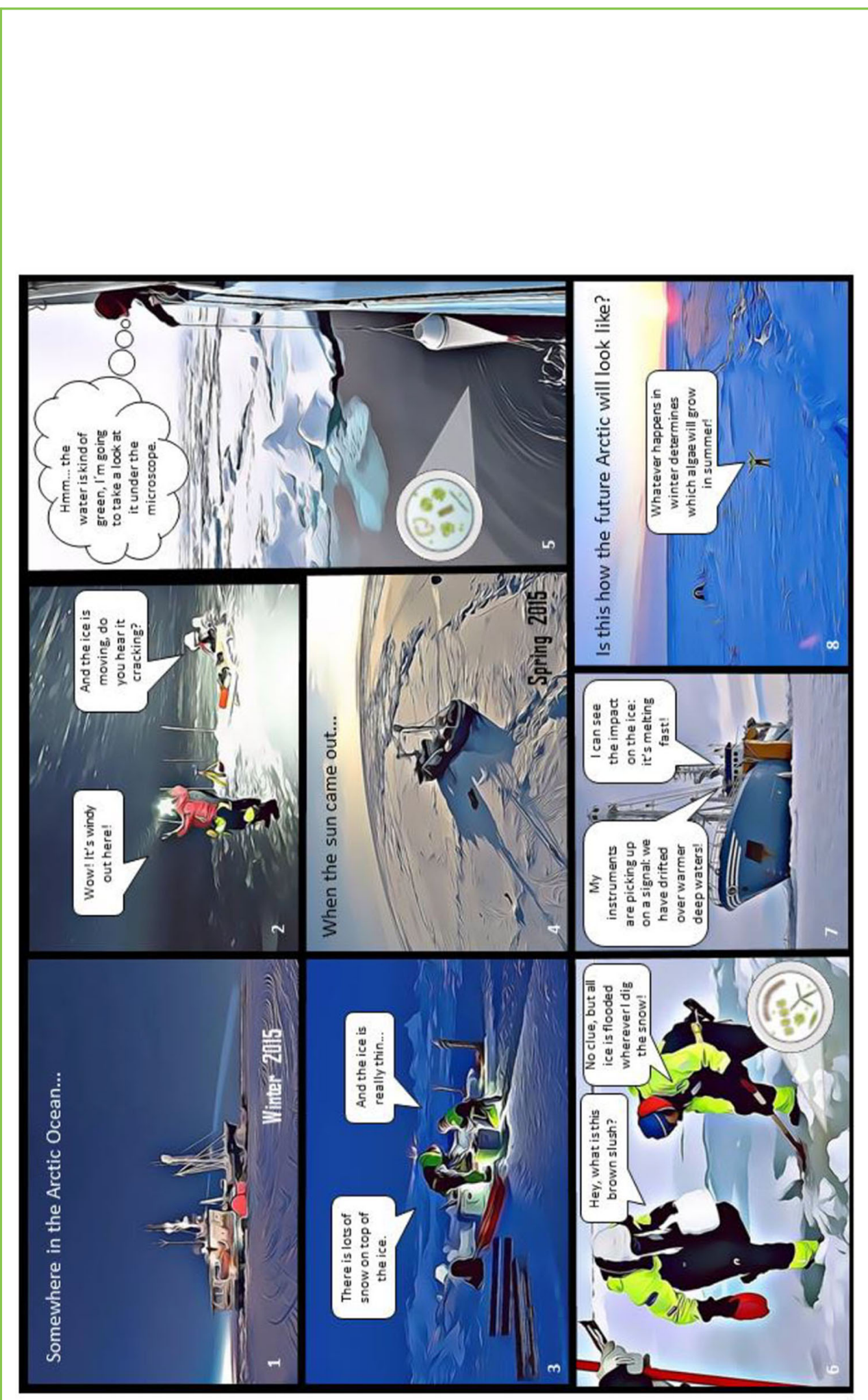

ำ 


\section{HEAVY SNOW PUSHES THE ICE SURFACE BELOW WATER AND LETS IT FLOOD}

Throughout our research expedition, our colleagues, the sea-ice physicists, found an unexpectedly deep layer of snow on top of the sea ice. This layer of snow was approximately half a meter thick. The snow accumulated on top of the sea ice during several storms earlier in the winter [5].

We found that the sea ice was very thin in relation to the deep snow layer. The fluffy texture of snow makes it a highly effective insulating blanket over the ice. This keeps the ice warm, compared with the cold atmosphere, and therefore prevents the ice from growing thicker during the cold winter.

On several occasions, we saw that the weight of the heavy snow pushed the surface of the ice below the water level. Imagine sitting on a swimming float in a pool. This caused the snow and ice to be flooded with seawater, which created a layer of slush. Together with the water, small amounts of algae were brought to the top of the ice. These algae acted in a similar way as seeds would and started an algal community in the slush layer, which explained our finding of the water column species. The slush creates a good place for algae to grow and reproduce, because there is more sunlight available than under the ice and there are less animals (zooplankton) eating them [4].

\section{SEA ICE CAN ALSO MELT FROM BELOW}

Melting of the ice can also make it thinner and lighter in relation to the snow cover and lead to surface flooding. In addition to being melted by sunlight in spring and summer, sea ice can melt from below even if the water is just a few degrees warm. During storms, the strong winds stir the ice and the ocean below the ice, mixing up warmer water from deeper layers to the surface where it melts the ice [7]. This is a special process that happens in certain parts of the Arctic, where warm ocean currents from the North Atlantic flow into the Arctic under the ice cover (Figure 1). This warm Atlantic Water is usually about $2^{\circ} \mathrm{C}$, which is a few degrees warmer than freezing Arctic waters at $-2^{\circ} \mathrm{C}$. With global ocean warming, we can expect that at some point in the future, the ocean will be able to melt the sea ice from below even without the help of storms: warm Atlantic water under the ocean surface only needs to be as warm as $5^{\circ} \mathrm{C}$ to melt sea ice very effectively, without the extra stirring caused by storms [8].

\section{CONCLUSIONS-WHAT WILL THE FUTURE ARCTIC LOOK LIKE FOR ALGAE?}

We think that during our expedition we saw what lies ahead for new algal life in the Arctic. We know ice is getting thinner and thus snow cover may get thicker in relation to the ice. This could make the 


\section{ECOSYSTEM}

An ecosystem is a group or community of interconnected living organisms and their environment. Examples of marine ecosystems include coral reefs, deep sea, and of course Arctic ecosystems. occurrences of slush layers more common and make it an important habitat for algae in the future. Deeper snow covers resulting from more frequent storms may also make it more common.

Winter storms are increasing in frequency and this is likely due to climate change. As the Arctic sea ice continues to thin, it is becoming more sensitive to these winter storms. We expect that the ice will break more easily and allow more sunlight to pass through in the future, which could make algae growth below the ice happen more often.

Our research helps to predict how the different parts of the Arctic sea ice cover respond to climate change and how the Arctic ecosystems may change as a consequence. Yet there are still several questions we have no answer to: for example, is this happening all around the Arctic already and how will it progress toward the North Pole? What will the ocean be like when all the ice has melted in the summer? What type of algae will live in the future Arctic? There is so much more to find out!

\section{ACKNOWLEDGMENTS}

The N-ICE2015 campaign was led and supported by the former Centre of Ice, Climate and Ecosystems at the Norwegian Polar Institute. The Research Council of Norway project Boom or Bust (no. 244646) was central for the biological part of the campaign, including supporting HK during the N-ICE2015 campaign. MF-M was supported by Program Arktis 2030 funded by the Ministry of Foreign Affairs and the Ministry of Climate and Environment, Norway (project ID Arctic). We would also like to thank the project leaders and fellow scientists on $\mathrm{N}-$ ICE2015, and the captains and crew of RV Lance for their assistance. AM acknowledges support from the ARC Centre of Excellence for Climate Extremes (CE170100023). PI was supported by the Norwegian Research Council project 287871.

\section{REFERENCES}

1. Meier, W. N., Hovelsrud, G. K., van Oort, B. E. H., Key, J. R., Kovacs, K. M., Michel, C., et al. 2014. Arctic sea ice in transformation: a review of recent observed changes and impacts on biology and human activity. Rev. Geophys. 51:185-217. doi: 10.1002/2013RG000431

2. Granskog, M. A., Assmy, P., Gerland, S., Spreen, G., Steen, H., and Smedsrud, L. H. 2016. Arctic research on thin ice: consequences of Arctic sea ice loss. Eos Trans. AGU 97:22-6. doi: 10.1029/2016EO044097

3. Assmy, P., Fernández-Méndez, M., Duarte, P., Meyer, A., Randelhoff, A., Mundy, C. J., et al. 2017. Leads in Arctic pack ice enable early phytoplankton blooms below snow-covered sea ice. Sci. Rep. 7:40850. doi: 10.1038/srep40850

4. Fernández-Méndez, M., Olsen, L. M., Kauko, H. M., Meyer, A., Rösel, A., Merkouriadi, I., et al. 2018. Algal hot spots in a changing Arctic Ocean: sea-ice 
ridges and the snow-ice interface. Front. Mar. Sci. 5:75. doi: 10.3389/fmars. 2018.00075

5. Graham, R. M., Itkin, P., Meyer, A., Sundfjord, A., Spreen, G., Smedsrud, L. H., et al. 2019. Winter storms accelerate the demise of sea ice in the Atlantic sector of the Arctic Ocean. Sci. Rep. 9:9222. doi: 10.1038/s41598-019-45574-5

6. Kauko, H. M., Taskjelle, T., Assmy, P., Pavlov, A. K., Mundy, C. J., Duarte, P., et al. 2017. Windows in Arctic sea ice: light transmission and ice algae in a refrozen lead. J. Geophys. Res. Biogeosci. 122:1486-505. doi: 10.1002/2016JG003626

7. Meyer A., Fer I., and Sundfjord A. 2017. Mixing rates and vertical heat fluxes north of Svalbard from Arctic winter to spring. J. Geophys. Res. Oceans 122:4569-86. doi: 10.1002/2016JC012441

8. Duarte, P., Sundfjord, A., Meyer, A., Hudson, S. R., Spreen, G., and Smedsrud, L. H. 2020. Warm Atlantic Water explains observed sea ice melt rates north of Svalbard. J. Geophys. Res. Oceans. 125:e2019JC015662. doi: 10.1029/2019JC 015662

SUBMITTED: 31 October 2019; ACCEPTED: 02 July 2020; PUBLISHED ONLINE: 28 October 2020.

EDITED BY: Penelope Kate Lindeque, Plymouth Marine Laboratory, United Kingdom

CITATION: Kauko HM, Fernández-Méndez M, Meyer A, Rösel A, Itkin P, Graham RM and Pavlov AK (2020) The Future of the Arctic: What Does It Mean for Sea Ice and Small Creatures? Front. Young Minds 8:97. doi: 10.3389/frym.2020.00097

CONFLICT OF INTEREST: The authors declare that the research was conducted in the absence of any commercial or financial relationships that could be construed as a potential conflict of interest.

COPYRIGHT @ 2020 Kauko, Fernández-Méndez, Meyer, Rösel, Itkin, Graham and Pavlov. This is an open-access article distributed under the terms of the Creative Commons Attribution License (CC BY). The use, distribution or reproduction in other forums is permitted, provided the original author(s) and the copyright owner(s) are credited and that the original publication in this journal is cited, in accordance with accepted academic practice. No use, distribution or reproduction is permitted which does not comply with these terms.

\section{YOUNG REVIEWERS}

\section{ST. MARGARET'S CE JUNIOR SCHOOL, AGES: 9-10}

We are Jamie, Lauren, Vaishali, Hannah, Yasmin, Shreyan, and Avleen. We are all keen scientists and really had fun during the review process. We are proud that we are influencing how other children will learn, and our teachers said we returned to our classroom buzzing. 

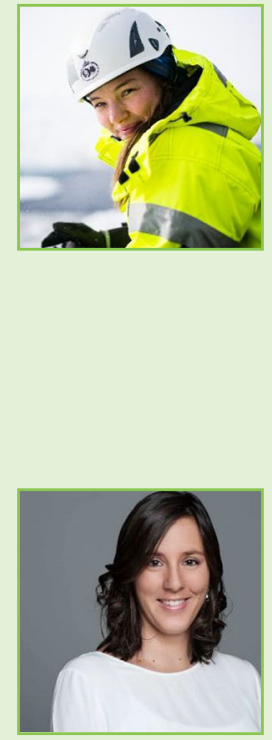

\section{AUTHORS}

\section{HANNA M. KAUKO}

Dr. Hanna Kauko is interested in the relationship between light and algae and how this affects primary production and light conditions in the ocean. She completed her PhD studies on this topic joining the N-ICE2015 campaign at the Norwegian Polar Institute. By using observations, she aims to understand microalgal ecology in the polar oceans and provide knowledge for modeling and management purposes. Currently she is a post-doc researcher at the Norwegian Polar Institute, working on Southern Ocean phytoplankton. *hanna.kauko@npolar.no; *hanna.kauko@alumni.helsinki.fi

\section{MAR FERNÁNDEZ-MÉNDEZ}

Dr. Mar Fernández-Méndez is an enthusiastic marine microbiologist who enjoys studying the role of algae in the world's oceans. After working in the Arctic for 7 years, including the N-ICE2015 campaign at the Norwegian Polar Institute, and investigating the effects of climate change on primary production in cold waters, she has now moved toward warmer waters to study the potential of phytoplankton to remove carbon from the atmosphere, thereby helping mitigate global warming. Her current position is based at GEOMAR Helmholtz Zentrum für Ozeanforschung in Kiel, Germany, and her field work takes place in Gran Canaria and Perú.

${ }^{\dagger}$ Present address: Mar Fernández-Méndez, Biological Oceanography Department, GEOMAR Helmholtz-Zentrum für Ozeanforschung Kiel, Kiel, Germany

\section{AMELIE MEYER}

Dr. Amelie Meyer is passionate about climate variability, polar science, and ocean circulation. Her work looks at how and why the polar oceans are changing, combining observations, reanalysis products, and climate models. Amelie has spent several months both in the Arctic and in the Southern Ocean collecting data to answer these questions, including taking part in the 6 months-long N-ICE2015 expedition in 2015 while working at the Norwegian Polar Institute. She currently works for the ARC Centre of Excellence for Climate Extremes based at IMAS, at the University of Tasmania in Australia.

${ }^{\dagger}$ Present address: Amelie Meyer, Institute for Marine and Antarctic Studies, University of Tasmania, Hobart, TAS, Australia

†Present address: Australian Research Council Centre of Excellence for Climate Extremes, University of Tasmania, Hobart, TAS, Australia

\section{ANJA RÖSEL}

Dr. Anja Rösel completed her PhD in polar remote sensing, studying the sea ice from satellite images. To learn more about the processes in reality, she decided to apply for a position with more field work at the Norwegian Polar Institute. There she got the opportunity to join the N-ICE2015 expedition. Currently she works at the German Aerospace Center (DLR) in Oberpfaffenhofen, Germany, and analyzes satellite images using artificial intelligence. 


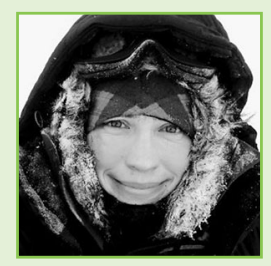

\section{POLONA ITKIN}

Dr. Polona Itkin is intrigued by the recent changes in how the Arctic sea ice moves. While the reasons for this lies in the atmosphere, ocean, and in the thinner ice itself, new motion patterns also influence all the boundary layers. The N-ICE2015 teamwork, achievements, and the remaining research challenges inspired her to join the next large Arctic research project-MOSAiC (https://www.mosaic-expedition.org). As part of this expedition, Polona will explore the role of deformed ice (pressure ridges and leads) for snow accumulation. She is currently a research scientist at the UiT, The Arctic University of Tromso and an associate of the Colorado State University, Fort Collins, CO, USA.

${ }^{\dagger}$ Present address: Polona Itkin, Earth Observation Laboratory, Department of Physics and Technology, UiT The Arctic University of Norway, Tromsø, Norway

${ }^{\dagger}$ Present address: Cooperative Institute for Research in the Atmosphere, Colorado State University, Fort Collins, CO, United States

\section{ROBERT M. GRAHAM}

Dr. Robert Graham is a climate scientist with a passion for ice. His research focuses on the Arctic Ocean as well as the Southern Ocean around Antarctica. He has used observations, and climate models to explore ongoing climate change in these regions, as well as past and future changes on timescales of tens to thousands of years. Robert worked as a post-doc at the Norwegian Polar Institute on the $\mathrm{N}$-ICE2015 project from 2015 to 2019. He is now investigating how long-term weather forecasts can be used to manage hydropower resources in Scotland at Strathclyde University, Glasgow.

${ }^{\dagger}$ Present address: Robert M. Graham, Department of Civil and Environmental Engineering, University of Strathclyde, Glasgow, United Kingdom

\section{ALEXEY K. PAVLOV}

Dr. Alexey K. Pavlov is an interdisciplinary researcher trying to understand the big changes that are happening in the Arctic Ocean and its ecosystem. He is particularly interested in the fate of sunlight in the Arctic Ocean and sea ice, and the many connections that light has with physical, biogeochemical, biological processes, and living organisms in the Arctic. As a post-doctoral researcher at the Norwegian Polar Institute, Alexey was lucky to join the N-ICE2015 expedition. He is currently a scientist at the Institute of Oceanology of the Polish Academy of Sciences (Sopot, Poland) and Akvaplan-niva (Tromsø, Norway).

${ }^{\dagger}$ Present address: Alexey K. Pavlov, Institute of Oceanology, Polish Academy of Sciences, Sopot, Poland

${ }^{\dagger}$ Present address: Akvaplan-niva, Tromsø, Norway 